E-ISSN : 2620-5858

\title{
Nilai Nasionalisme dalam Hikayat Perang Sabil Teungku Chik Pantee Kulu
}

\author{
Syamsul Rizal \\ Institut Agama Islam Negeri Langsa \\ putradw212@gmail.com
}

\begin{abstract}
This article discusses nationalism in the sabil war saga written by Teungku Chik Pantee Kulu. The sabil war saga written by Tengku Chik Pantee Kulu is a saga found in Acehnese society and can give the spirit of defending the country after listening to it. This saga was written in 1873 after he returned from Mecca and at that time Aceh fought against the Dutch. This research method uses literature study with a hermeneutic approach. The primary data source is Ali Hasjmy's book, Aceh Literary Contributions in the Development of Indonesian Literature, Jakarta: Bulan Bintang, 1977. The results of the analysis show that there are five values of nationalism in the sabil war saga by Teungku Chik Pante Kulu, namely love for the homeland, self-sacrifice, interest country above personal interests, has a heroic spirit, and does not give up easily.
\end{abstract}

Keywords: Hikayat, Nationalism, Sabil War, Teungku Chik Pantee Kulu

Abstrak: Artikel ini membahas nasionalisme dalam hikayat perang sabil yang dikarang oleh Teungku Chik Pantee Kulu. Hikayat perang sabil yang ditulis oleh Teungku Chik Pantee Kulu adalah hikayat yang terdapat dalam masyarakat Aceh dan dapat memberikan semangat bela negara setelah mendengarkannya. Hikayat ini ditulis pada tahun 1873 sepulangnya beliau dari Mekkah dan ketika itu Aceh berperang melawan Belanda. Metode penelitian ini menggunakan studi pustaka dengan pendekatan hermeneutik. Sumber data primer adalah buku karangan Ali Hasjmy, Sumbangan Kesusastraan Aceh dalam Pembinaan Kesusastraan Indonesia. Hasil analisa diketahui ada lima nilai nasionalisme dalam hikayat perang sabil karangan Teungku Chik Pante Kulu, yakni cinta tanah air, rela berkorban, kepentingan negara di atas kepentingan rpibadi, berjiwa pahlawan, dan tidak mudah menyerah.

Kata Kunci: Hikayat, Nasionalisme, Perang Sabil, Teungku Chik Pantee Kulu

\section{Pendahuluan}

Belanda menyatakan perang terhadap Aceh sejak tahun 1873 dan perang baru berakhir pada tahun 1912. Peperangan Aceh yang berkepanjangan ini mengakibatkan banyak korban dari rakyat Aceh saat melakukan perlawanan terhadap Belanda pada kurun waktu kedua abad ke-19. Akibat perang ini diperkirakan telah mengurangi $1 / 3$ populasi orang Aceh. Sementara menurut taksiran Anthony Reid, tercatat sejak tahun 1873-1914 sekitar 13.412 serdadu Belanda yang tewas (Alfian, 1992). Perlawanan rakyat Aceh selama kurang lebih 4 dekade tidak mudah untuk ditaklukkan oleh Belanda.

Rakyat Aceh dinilai oleh berbagai kalangan memiliki semangat perjuangan dan kegigihan yang luar biasa. Salah satunya adalah penulis berkebangsaan Belanda H.C. Zentgraaff mengatakan bahwa “... orang-orang Aceh, baik pria maupun wanita, pada umumnya telah berjuang dengan gigih sekali untuk sesuatu yang mereka pandang sebagai kepentingan nasional atau agama mereka...". Sementara itu Pierre Heijboer mengatakan bahwa “... orang-orang Aceh ternyata

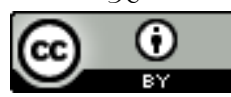

This work is licensed under a Creative Commons Attribution 4.0 International License 
VOLUME 14 NOMOR 1 TAHUN 2021

P-ISSN : 1979-9357

E-ISSN : 2620-5858

bukan saja pejuang-pejuang yang fanatik, akan tetapi mereka juga tergolong pembangun kubu-kubu pertahanan yang ulung..." (Alfian, 1992).

Dua bentuk perlawanan masyarakat Aceh adalah dengan mengangkat senjata dan perlawanan terbuka. Hal ini sebagai bentuk dari rasa cinta masyarakat Aceh terhadap tanah air dan bangsanya. Keberanian ini tumbuh dalam jiwa masyarakat Aceh yang digerakkan oleh nilai-nilai yang ditemukan dalam hikayat perang sabil. Hal ini disebabkan kandungan isi hikayat perang sabil terdapat ideologi untuk melakukan perlawanan kepada musuh yang akan menghancurkan agama, negara dan bangsa. Kumpulan tulisan dalam hikayat perang sabil yang ditulis oleh ulama-ulama, berisikan semangat berperang melawan ketidakadilan yang dapat merusak sendi-sendi agama dalam kehidupan masyarakat. Hal ini senada dengan yang dikatakan oleh Hasjmy bahwa hikayat perang sabil sebagai "sastra perang" ditulis diwaktu perang dan bagi siapa yang membacanya tergugah jiwanya untuk berperang.

Biasanya hikayat perang sabil dibacakan oleh teungku-teungku dayah atau masyarakat yang dapat membaca Arab Melayu. Dayah, meunasah yang dianggap aman menjadi tempat untuk membaca hikayat perang sabil (Hasjmy, 1977). Tempat yang aman menjadi perhatian yang sangat penting untuk dijadikan lokasi pembacaan hikayat perang sabil dikarenakan makna yang terkandung dalam hikayat tersebut dapat menumbuhkan semangat anti penjajahan. Semangat anti penjajahan pada masyarakat Aceh teraktualisasi dalam peperangan melawan Belanda. Belanda dalam pandangan masyarakat Aceh adalah musuh yang merusak sendi-sendi agama Islam di Aceh. Berlandaskan pada sudut pandang (ideologi) itu, rakyat Aceh berkesimpulan bahwa kolonial atau penjajah itu sebagai kaphe (kafir; dalam bahasa Aceh). Peperangan dan perlawanan terhadap Belanda dengan berdasarkan keyakinan telah membentuk paradigma atau cara pandang serta cara berpolitik dan corak kehidupan masyarakat Aceh.

Perlawanan masyarakat Aceh banyak di bawah pimpinan ulama, sehingga perlawanan dan peperangan dalam masyarakat Aceh menjadi suci dan sakral. Agama memberikan peran penting terhadap kesucian dan kesakralan perang di Aceh. Dengan peran agama dan ulama maka dalam masyarakat Aceh muncul semangat perang suci yang dalam agama Islam disebut dengan "sabililllah". Ulama memberikan dogma kepada masyarakat Aceh yang berjuang bahwa kehidupan di dunia adalah kehidupan sementara yang singkat. Orang Islam yang mati diwaktu melakukan perjuangan untuk melawan ketidakadilan dan musuh yang akan merusak agama maka kematian bagi mereka adalah awal dari kehidupan yang abadi. Kehidupan yang penuh dengan kenikmatan serta kehidupan yang dirindukan oleh setiap muslim yaitu kehidupan di surga. Sebab mati dalam perang melawan kafir adalah syahid di jalan Allah.

Dengan ideologi tersebut terbangun hikayat perang sabil yang ada di Aceh. Ulama menggunakan media hikayat dalam membangkitkan spirit perjuangan masyarakat Aceh untuk melawan penjajahan Belanda. Para ulama mempunyai kesadaran bahwa hikayat lebih diminati oleh masyarakat karena terdapat nuansa

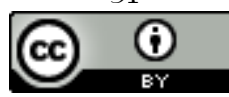

This work is licensed under a Creative Commons Attribution 4.0 International License 
VOLUME 14 NOMOR 1 TAHUN 2021

P-ISSN : 1979-9357

E-ISSN : 2620-5858

seni dan dibacakan dengan gaya syair, bila dibandingkan dengan ceramah dan khutbah.

Hikayat perang sabil memberikan pengaruh yang luar biasa dalam kehidupan masyarakat Aceh. Pengaruhnya dapat dilihat bagaimana perlawanan yang dilakukan masyarakat Aceh terhadap penjajahan Belanda. Perlawanan yang dilakukan oleh masyarakat Aceh dikenal dengan sebutan "poh kaphee". Perlawanan masyarakat Aceh tidak hanya dilakukan dalam bentuk massal tetapi juga dilakukan dalam bentuk perorangan. Belanda menyebutkan perlawanan masyarakat Aceh dengan istilah "Atjeh Moord". Kern berpendapat bahwa masyarakat Aceh melakukan serangan secara personal sejumlah 79 serangan pada tahun 1910 hingga 1912 dengan menewaskan 99 orang Belanda yang perhitungannya 12 orang tewas dan yang mengalami luka-luka berjumlah 87 orang. Kern sendiri menyimpulkan bahwa metode penyerangan secara personal tersebut dilatarbelakangi oleh gagasan-gagasan perang sabil dengan disertai rasa kebencian pada orang-orang kafir (Belanda) (Alfian, 1992).

Ternyata, peristiwa penyerangan secara personal tersebut menjurus pada dua dasar pengasumsian, pertama, bahwa kandungan hikayat perang sabil memiliki nilai-nilai nasionalisme dan patriotisme. Sebab, ketika rakyat Aceh diperdengarkan kisah hikayat perang sabil tersebut timbul keberanian untuk melawan terhadap Belanda meskipun Belanda memiliki kekuatan besar. Kedua, pentingnya peran agama terhadap pertumbuhan nilai-nilai nasionalisme dan patriotisme rakyat Aceh. Hal tersebut dikarenakan faktor agama dalam kehidupan masyarakat Aceh diibaratkan seperti sisi mata uang yang tidak dapat dipisahkan satu dengan yang lain. Sebagaimana yang termaktub di dalam hadi madjah yang menyatakan bahwa; "hukom ngon adat hanjet mecre, lage zat ngon sifeut" Artinya; "hukum syara' atau syari'at dan hukum adat tidak dapat dipisahkan, ibarat tidak terpisahkan antara zat Tuhan dengan sifat-Nya" (Hasjmy, Himpunan Hadi Madja , 1958). Hadi madjah menerangkan bahwa terdapat dua pondasi yang tertanam dalam masyarakat Aceh, dua pondasi tersebut adalah agama dan tradisi. Kedua hal tersebut yang kemudian mengkristal dalam kehidupan masyarakat dan akhirnya menjadi ideologi. Ideologi tersebut yang menjadi kekuatan masyarakat Aceh dalam berperang melawan Belanda.

Dari pemaparan tersebut, ditemukan kekhawatiran secara akademisi dalam kaitannya dengan hikayat perang sabil, yaitu; apa sebab masyarakat Aceh memiliki keberanian dan mampu bertahan melawan Belanda yang memiliki kemampuan dan peralatan perang yang lebih baik bila dibandingkan dengan masyarakat Aceh.

\section{Metode Penelitian}

Penelitian ini adalah penelitian pustaka yang studinya adalah hasil pemikirin seseorang yang berbentuk karya sastra (hikayat) namun penelitian ini bukanlah penelitian sastra yang melihat keindahan bahasa atau struktur kalimat

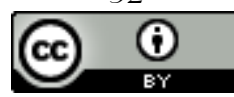

This work is licensed under a Creative Commons Attribution 4.0 International License 
VOLUME 14 NOMOR 1 TAHUN 2021

P-ISSN : 1979-9357

E-ISSN : 2620-5858

Penelitian ini memanfaatkan data tekstual baik dari sumber primer ataupun dari sumber skunder, maka pendekatan yang digunakan adalah hermeneutik.

Jenis data dalam penelitian ini terbagi atas dua bagian, yaitu; primer dan skunder. Data primer dalam penelitian disertasi ini adalah: Hikayat Perang Sabil yang ditulis oleh Teungku Chik Pantee Kulu yang terdapat dalam buku A. Hasjmy yang berjudul Apa Sebab Rakyat Aceh Sanggu Berperang Puluhan Tahun Melawan Agresi Belanda. Dalam penelitian ini juga tidak akan membandingkan kata demi kata, dan membandingkan susunan kalimat serta gaya bahasa yang terdapat dalam naskah, namun lebih cendrung kepada upaya untuk menganalisis teks dan menginterpretasikan teks untuk mencari nilai-nilai yang terkandung di dalamnya. Kedua, naskah hikayat Perang Sabil yang terdapat di dalam buku tersebut di atas masih tertulis dalam huruf Arab Melayu dengan menggunakan bahasa Aceh.

Data sekunder dalam penelitian ini, di antaranya adalah Hasjmy, Sumbangan Kesusastraan Aceh dalam Pembinaan Kesusastraan Indonesia, Jakarta: Bulan Bintang, 1977. Ibrahim Alfian, Perang di Jalan Allah Perang Aceh 1873-1912, Jakarta: Pustaka Sinar Harapan, 1987. Ibrahim Alfian, Wajah Aceh dalam Lintasan Sejarah, Banda Aceh: Pusat Dokumentasi dan Informasi Aceh, 1999.

\section{Hasil dan Pembahasan}

\section{Selayang pandang Nasionalisme}

Karya Hans Kohn dengan judul "Nasionalisme, Arti dan Sejarahnya" memberikan pemahaman bahwa nasionalisme merupakan salah satu dari kekuatan yang menentukan dalam sejarah modern (Hutauruk, 1984). Nasionalisme sebagai bentuk pemahaman berbangsa, yang memiliki arti bahwa suatu bangsa memiliki rasa kecintaan terhadap tanah airnya, atau rasa kecintaan pada bangsanya sendiri (Junanto, 2013). Sehingga Bahasa Indonesia mengistilahkan nation atau bangsa, yang dipergunakan sebagai penerjemah ras ( race) dan folk. Dari ketiga kata-kata itu memiliki perbedaan makna, yakni kata nation merupakan bangsa yang terbentuk dari sekumpulan orang dalam menciptakan satu kesatuan dari beberapa unsur dengan memiliki kesamaan cita-cita dan rindu akan kehidupan bernegara. Sedang ras memiliki makna bangsa menurut pengertian antropologi, yakni masih dari satu rumpun (satu keturunan). Lain halnya folk yang memiliki makna kelompok orang yang sama dari sisi sosial dan budaya kemasyarakatannya (Herdiawanto \& Jumanta , 2010).

Nasionalisme bisa juga disebut suatu keadaan psikologis seseorang yang terjadi dengan serta merta terhadap negara dan bangsa dalam bentuk pengabdian dan pelayanan loyalitas secara menyeluruh (Rosyada, 2003). Nasionalisme juga dipahami sebagai wujud pola pikir, sikap dan perbuatan dengan memperlihatkan sifat setia, sifat peduli dan sifat menghargai setinggi-tingginya kepada bangsa, lingkungan, fisik, sosial, budaya dan ekonomi serta politik kebangsaannya (Mustari, 2014). Arti dari bangsa (nation) itu sendiri sebenarnya menunjukkan

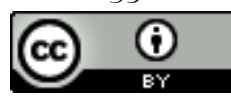

This work is licensed under a Creative Commons Attribution 4.0 International License 
VOLUME 14 NOMOR 1 TAHUN 2021

P-ISSN : 1979-9357

E-ISSN : 2620-5858

kumpulan manusia dengan memiliki kesamaan dari bahasa, adat istiadat, asal usul, budaya, seperjuangan dan sependeritaan, serta negara yang ditempatinya.

Junanto memberikan pemaparan mengenai berbagai pengertian nasionalisme (Junanto, 2013) sebagai berikut:

1. Encyclopedia Britania, nasionalisme adalah keadaan jiwa setiap individu yang merasa bahwa setiap orang memiliki kesetiaan dalam keduniaan (sekuler) tertinggi kepada Negara kebangsaan.

2. International Encyclopedia of The Social Sciences, nasionalisme adalah suatu ikatan yang mengikat kesatuan masyarakat modern dan memberi keabsahan terhadap klaim (tuntutan) kekuasaan.

3. Nasionalisme adalah suatu paham yang menganggap bahwa kesetiaan tertinggi atas setiap pribadi harus diserahkan kepada negara kebangsaan atau nation state.

Nasionalisme Indonesia merupakan bentuk pemahaman yang terwujud dari rasa cinta akan kebangsaan Indonesia yang terletak pada persatuan, kesatuan serta kepentingan pribadi maupun golongan dengan senantiasa mengakui akan kesamaan nilai-nilai kemanusiaan dan harga diri tiap-tiap bangsa, menghormati dan menjunjung tinggi kedaulatan tiap bangsa dengan mempererat jalinan persahabatan dan kerja sama terhadap seluruh bangsa. Ringkasnya, nasionalisme Indonesia merupakan pemahaman berbangsa dengan berlandaskan jiwa kewarganegaraan.

Asal kata nasionalisme dari bahasa Inggris nation yang memiliki arti "bangsa". Dikarenakan dibubuhi akhiran -isme sehingga kata ini menjadi kata sifat yang bermakna cara berpikir seseorang atau suatu golongan (ideologis) dan wawasan yang dipergunakan oleh segolongan manusia. Sehingga nasionalisme dapat diartikan sebagai bentuk pemahaman atau petunjuk ajar dalam mencintai bangsa dan negara berdasarkan pada pemahaman kewarganegaraan/kewargaan sesuai dengan daya kemampuan secara kolektif demi pencapaian, pertahanan dan pengabdian jati diri (identitas), kejujuran (integritas), kejayaan (kemakmuran) dan otoritas kewenangan (kekuatan) bangsa (Yatim, 1999). Nasionalisme mengandung makna kesadaran dan semangat cinta tanah air, memiliki rasa kebangsaan bangsa, atau memelihara kehormatan bangsa" (Alwi, 2007). Sebagaimana dalam karyanya, Chotib Djazuli mengutip pernyataan Hitler, "nasionalisme adalah sikap dan semangat berkorban untuk melawan bangsa lain" (Chotib \& dkk, 2007).

Sejarah asal kata nation terambil dari bahasa Prancis yang pada mulanya memakai asal kata nasci yang berasal dari bahasa Latin. Kecenderungan perubahan peristilahan terjadi secara gramatikal pada kata ini, yakni unsurnya lebih bersifat penghinaan dan merendahkan (peyoratif) terhadap ras, suku atau keturunan bagi orang-orang yang diduga memiliki sifat buruk (kasar; kurang lemah lembut), dan tidak sopan berdasarkan parameter orang-orang Romawi. Menurut substansialnya, mula-mula penggunaan peristilahan tersebut terdapat diberbagai

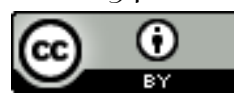

This work is licensed under a Creative Commons Attribution 4.0 International License 
VOLUME 14 NOMOR 1 TAHUN 2021

P-ISSN : 1979-9357

E-ISSN : 2620-5858

dokumen terdahulu, semisal tulisan Abas Sieyes yang terdapat pada selebaran (pamflet) dan penyusunan Deklarasi Hak Asasi Manusia dan Warga Negara ketika terjadi Revolusi Prancis di tahun 1789. Selanjutnya istilah "nasionalisme" terus menyebar dan berwujud "kekuasaan rakyat" yang selalu dipergunakan menjadi bentuk program untuk melawan kekuasaan monarki.

Begitu beragam jenis dari nasionalisme itu, sebab hal itu bergantung pada pengaruh aspek yang mendominasi, baik itu aspek ekonomi, politik dan aspek budaya. Menurut Hall ragam nasionalis terbagi atas lima hal. Pertama, nasionalisme resorgimento, yakni kemunculan nasionalisme dari dasar. Biasanya yang mempelopori kemunculan nasionalisme ini adalah banyaknya jumlah para cendikiawan yang terus meningkat sebab adanya pendidikan. Kaum terpelajar ini merupakan manusia-manusia modernis, liberal dan demokrat yang menstimulasi pembentukan karakter preskriptif (integritas normatif; kaku) di wilayah hukum (teritorial) mereka sendiri selaku warga negara (nation state; negara bangsa) yang liberal dan demokratis. Aspek lainnya yang menstimulasinya ialah adanya pertumbuhan perekonomian dari masyarakat agraris menjadi masyarakat industrial, dari desa menjadi perkotaan yang disebabkan adanya proses industrialisasi. Jenis ini tumbuh di Eropa pada abad 18 hingga abad 19 (Chotib \& $\mathrm{dkk}, 2007)$

Kedua, nasionalisme integratif, yakni tumbuhnya nasionalisme sebab pengaruh adanya eksploitasi perasaan dendam akibat penindasan dari bangsa lain. Nasionalisme ini mempengaruhi pembauran (integrasi) secara menyeluruh sisi kehidupan berbangsa yang menjadi rancangan guna melawan bangsa-bangsa lain yang melakukan penindasan. Contoh nasionalisme seperti ini dikembangkan kaum Fascisme Italia dan Naziisme di Jerman (Retno, 2007).

Ketiga, nasionalisme romatik adalah bentuk nasionalisme etnis dimana negara memperoleh kebenaran politik sebagai suatu yang alamiah dan merupakan eksprresi dari bansa atau ras. Keempat, nasionalisme budaya adalah nasionalisme dimana negara meperoeh kebenaran politik dari budaya bersama dan tidak bersifat turun-temurun seperti warna kulit. Kelima, nasionalisme kenegaraan adalah merupakan variasi nasionalisme kewarga negaraan yang sering dikombinasikan dengan nasionalisme etnis. Keenam, nasionalisme agama adalah nasionalisme dimana negara memperoleh legitimasi politik dari persamaan agama.

\section{Nasionalisme Dalam Hikayat Perang Sabil}

Teungku Chik adalah julukan yang disematkan untuk tokoh keagamaan di Aceh, sebagaimana sebutan kiayi di pulau Jawa. Selain memiliki wewenang untuk berfatwa, teungku chik juga merupakan sebuah tradisi sebagai pengganti nama seseorang pada suatu wilayah tempat orang tersebut dilahirkan atau melakukan sebuah aksi tindakan. Sebagaimana Teungku Chik Di Tiro, beliau bernama Muhammad Saman yang dilahirkan di Cumbok Lamlo pada tahun $1251 \mathrm{H}$ atau bertepatan 1836 M, beliau wafat pada tahun 1891 M. Teungku Chik Tanoh Abee memiliki nama asli Abdul Wahab yang berasal dari Aceh Besar, Teungku Chik

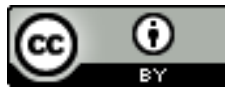

This work is licensed under a Creative Commons Attribution 4.0 International License 
VOLUME 14 NOMOR 1 TAHUN 2021

P-ISSN : 1979-9357

E-ISSN : $2620-5858$

Pantee Kulu yang memiliki nama Haji Muhammad, desa Pantee Kulu merupakan asal beliau dilahirkan (Drewes, 1979) .

Kesusastraan Aceh dan Melayu menggunakan peristilahan hikayat yang merupakan asal kata dari bahasa Arab; yakni hikayat, pada awalnya memiliki arti "peniruan". Secara lambat laun terjadi pergeseran, pengertian tersebut menjadi pemahaman sebuah kisah atau legenda. Awal penggunaan peristilahan hikayat pada kesustraan Arab ini disebabkan munculnya kebiasaan dalam bercerita sebagai penambah pemikat ketika menirukan dan memperagakan wujud perilaku. Lambat laun, hikayat tersebut hanya meninggalkan kata-kata, metode pembawaannya pun dilakukan cara ritmis, apalagi ketika pengarang kisah tersebut merubahnya menjadi tulisan yang dikhususkan bagi pembawa cerita (hikaya; imitator).

Wujud nasionalisme semestinya tercipta dari tiap-tiap warga negaranya melalui sikap mematuhi dan menghargai terhadap semua nilai dan norma hukum, adat istiadat dan peraturan perundangan yang telah diberlakukan oleh amanat konstitusi. Sebab, dengan nasionalisme tersebut akan tercipta kedaulatan, keadilan dan kemakmuran pada suatu negara. Sikap nasionalisme ini tergambar dalam hikayat perang sabil yang terdapat pada kitab karya Teungku Muhammad Chik Pantee Kulu. Begitu urgennya sikap nasionalisme itu, sebab Indonesia sempat mengalami darurat nasionalisme, terutama wilayah sebelah barat Indonesia, Aceh bersama partisipan separatis (GAM) dan wilayah sebelah timur Indonesia, Papua bersama partisipan separatisnya (OPM). Teungku Muhammad Chik Pantee Kulu menggambarkan pengkonsepan sikap nasionalisme berbangsa dan bernegara melalui pengadopsian dalam hikayat perang sabil sehingga penerapannya dapat dilakukan pada waktu sekarang ini, yakni dalam wujud sikap:

\section{Cinta Tanah Air}

Tiap-tiap warga negara berkewajiban memiliki rasa cinta tanah air, karena bila tidak ada rasa cinta, mustahil tercipta perbuatan baik, sebab secara kodrat, cinta merupakan bentuk pengabdian dan loyalitas (Zuhdy, 2018). Oleh sebab itu, begitu pentingnya cinta tanah air supaya tumbuhnya rasa cinta tersebut akan berdampak pada rela berkorban dalam wujud pengabdian dan loyalitas oleh tiaptiap warga negara terhadap bangsa dan negaranya. Secara spesifik, ada tiga dasar keistimewaan yang dimiliki oleh cinta itu sendiri, yaitu pertama sikap ta'dzim (apresiatif), kedua sikap ihtimäman (penuh perhatian), dan ketiga sikap mahabbah (kasih sayang) (Hazm, Ibnu, Thuq Al-Hamamah, fi Al-Ilfah wa Al-Ullat, 2005).

Dari ketiga anggapan di atas, pernyataan yang dapat penulis nyatakan adalah bahwa maksud dari cinta pada tulisan ini yaitu rasa mengasihi (perasaan kasih), atensi (perhatian) dan afeksi (kepedulian) dari seseorang terhadap tanah airnya. Menurut ilmu kejiwaan (psikologi), sejatinya rasa cinta itu memiliki kandungan elemen kasih dan sayang akan sesuatu. Selanjutnya dalam jiwa seseorang itu menimbulkan suatu keinginan untuk melakukan perawatan,

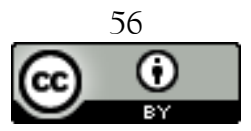

This work is licensed under a Creative Commons Attribution 4.0 International License 
VOLUME 14 NOMOR 1 TAHUN 2021

P-ISSN : 1979-9357

E-ISSN : 2620-5858

perlindungan dan pemeliharaan terhadap kemungkinan-kemungkinan munculnya berbagai gangguan yang membahayakan (Kamilin, 2014).

Pengkonsepan nasionalisme dalam bentuk cinta tanah air yang terdapat dalam hikayat perang sabil diceritakan dalam syair:

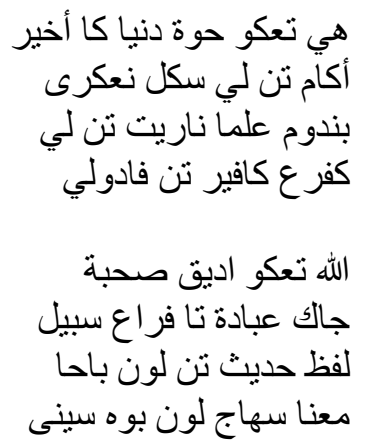

Hai teungku cut dunya ka akhir

Agama tan le segala negeri

Bandum ulama narit tan lee

Keu prang kafir tan le peduli

Allah teungku adek sahabat

Jak ibadah ta prang sabil

Lafadz hadis tan lon baca

Makna sahaja lon boh sinan

Artinya;

Wahai teungku cut dunia sudah akhir

Agama tidak lagi ada di semua negeri

Para ulama tidak lagi berdakwah

Untuk perang kafir tidak dihiraukan

Allah teungku adek sahabat

Melaksanakan ibadah dengan perang sabil

Lafadz hadis tidak saya baca

Hanya makna yang saya sampaikan di sini

Kandungan syair tersebut jelas memperlihatkan betapa besarnya cinta rakyat Aceh terhadap tanah air hingga menimbulkan semangat untuk mempertahankan negeri disaat Belanda datang menjajah dengan memohon pertolongan kepada Tuhan agar rakyat Aceh mendapatkan kekuatan demi menghalau para penjajah dari tanah air. Kemudian, dari berbagai literatur para ulama melalui tulisan menyatakan bahwa cinta tanah air merupakan landasan paling utama yang mesti warga negara miliki, salah satu di antaranya ungkapan

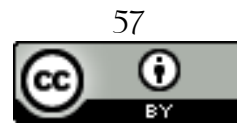

This work is licensed under a Creative Commons Attribution 4.0 International License 
VOLUME 14 NOMOR I TAHUN 2021

P-ISSN : 1979-9357

E-ISSN : 2620-5858

ulama yang begitu mengagumkan hingga menjadi sebuah ungkapan yang mampu memotivasi ialah hubbul wathan minal iman, "cinta tanah air adalah sebagian dari iman", sehingga mustahil untuk terjadi "tawar menawar" dalam mencintai tanah air, karena cinta tanah air merupakan sebagian dari iman (Asy'ari, 2007). Dalam kitab Tazkirah, Imam al-Qarafi mengungkapkan; memberikan pendidikan kepada seseorang dengan meninggalkan tanah air merupakan bagian dari kemaslahatan dalam ibadah haji.

Bung Hatta yang merupakan tokoh nasionalis Indonesia pun memberikan perhatiannya terhadap cinta tanah air. Perhatiannya tersebut pernah beliau ucapkan, yakni; "hanya ada satu tanah yang dapat disebut tanah airku, ia berkembang dengan usaha, dan usaha itu adalah usahaku". Perhatian cinta tanah air Bung Hatta yang lain dibuktikan melalui ucapannya dengan semangat juang yang tinggi, yaitu; "jika Indonesia belum merdeka, aku tidak akan menikah" (Muhibbuddin, 2014). Tanah air ada di sana, dimana ada cinta dan kedekatan hati, dimana tidak ada manusia yang menginjak manusia lainnya.

Beberapa bentuk cinta tanah air yang tersirat dalam hikayat perang sabil Teungku Chik Pantee Kulu diantaranya: pertama, perang melawan penjajah belanda. Mengusir penjajah dari negeri merupakan bukti kecintaan terhadap tanah air, hal ini karena kita tidak ingin negeri kita dikuasai oleh mereka para penjajah, para ulama dan umara saat itu mengumandangkan seruan untuk melakukan jihad melawan para penjajah. Sejarah mencatat bahwa sanya Aceh Indonesia pada umumnya pernah dijajah oleh belanda maka saat itu semua rakyat Aceh Indonesia melakukan perlawanan atas bentuk kecintaan mereka terhadap tanah air, para ulama yakni diantaranya memberikan fatwa tentang wajibnya membela tanah air dengan sebuah kaedah "hubbul wathan minal iman" Cinta tanah air sebagian dari iman (Setiawan, 2016).

Bentuk kedua dari cinta tanah air yang tersirat dalam hikayat perang sabil Teungku Chik Pantee Kulu adalah balasan bagi yang mau membela tanah air. Tengku Muhammad Chik Pante Kulu dalam syairnya beliau memberi semangat kepada mereka yang mau berjuang membela negara yakni dengan menguti beberapa rujukan dari Al-Quran dan hadist beliau mengatakan orang-orang yang meninggal dalam mati syahid maka akan mendapatkan syuruga tinggi serta juga akan mendapatkan bidadari.

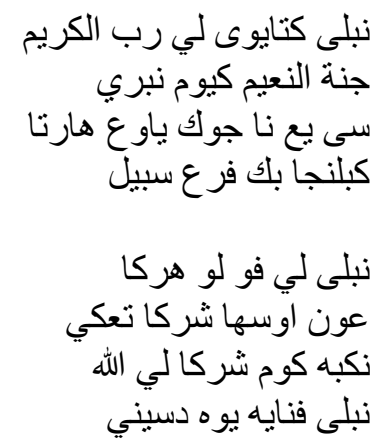

58

This work is licensed under a Creative Commons Attribution 4.0 International License 
VOLUME 14 NOMOR 1 TAHUN 2021

P-ISSN : 1979-9357

E-ISSN : 2620-5858

Neubloe goutanyo lee Rabbol Karim, Djannaton na'im geu yum neubri.

Soe yang na djook njawong hareuta,

Keu beulandja bak Prang Sabi.

Neubloe lee Po leu hareuga,

Ngon useuha syurga tinggi.

Neu keubah keu yum syurga lee Allah,

Neu bloo peunayoh yoh disini.

Artinya;

Dibelinya kita oleh Rabbul Karim

Jannatun na'im diberi harga

Siapa yang ada memberikan nyawa harta

Untuk menjadi bekal pada perang sabil

Dibeli oleh pemilik (Allah) banyak harga

Dengan usaha syurga tinggi

Disimpan untuk harga surga oleh Allah

Kamu beli bekal itu disini

Bentuk ketiga dari cinta tanah air yang tersirat dalam hikayat perang sabil Tengku Chik Pantee Kulu adalah berbakti kepada negara. Berbakti kepada dengan segenap jiwa dan raga juga merupakan salah satu bentuk cinta terhadap tanah air, dimana orang yang berbakti kepada sesuatu maka orang tersebut mencintai sesuatu tersebut. Tengku Muhammad Chik Pante Kulu dalam hikayatnya menjelaskan tentang orang yang mau berbakti kepada negara dengan melawan penjajah maka akan Allah berikan syurga tinggi kepada mereka.

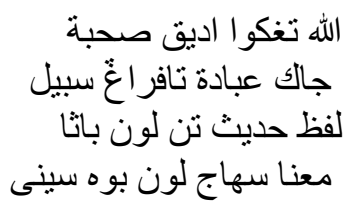

Allah teungku adeek sahabat,

Djak ibadat taprang Sabi.

Lafadz hadis tanlon baca,

Ma'na sahadja lon booh sinan.

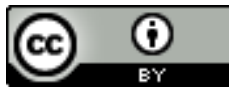

This work is licensed under a Creative Commons Attribution 4.0 International License 


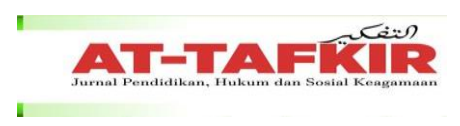

VOLUME 14 NOMOR 1 TAHUN 2021

P-ISSN : 1979-9357

E-ISSN : $2620-5858$

Artinya;

Wahai teungku adek sahabat

Pergi ibadah kita perang sabil

Lafad $z$ hadis tidak saya baca

Hanya makna yag saya taruh di situ

Syair tersebut menjelaskan bagaimana Tengku Chik Muhammad Pantee Kulu menggalakka para pejuang untuk membela negara dimana beliau memberikan sebuah gambaran kepada para pejuang agar tidak merasa ragu untuk membela tanah air karna pada dasarnya orang-orang yang membela tanah air akan mendapatkan balasan yang setimpal atas balasan yang dia kerjakan.

\section{Rela Berkorban}

Rela berkorban merupakan salah satu sikap yang fundamental dalam perjuangan, dikarenakan dalam setiap perjuangan dituntut untuk melakukan sebuah pengorbanan. Apa yang terjadi di masa peperangan adalah kerugian, pertumpahan darah, pembataian, dan dibunuh atau membunuh. Sehingga kerugian apakah itu kerugian materi atau non materi selalu mengiringi dalam setiap peperangan. Sebagai contoh ketika Aceh pada waktu masa konflik antara GAM (Gerakan Aceh Merdeka) dengan TNI, berapa banyak kerugian yang dialami oleh masyarakat Aceh. Pada masa tersebut banyak rumah, fasilitas umum seperti sekolah dibakar oleh pihak yang tidak bertanggung jawab. Banyak masyarakat Aceh yang terbunuh dengan tanpa diketahui alasan mengapa dia dibunuh, gadisgadis Aceh banyak yang diperkosa, perekonomian mati. Semua apa yang terjadi pada masa konflik adalah kerugian dari materi ataupun non materi.

Dengan melihat kerugian yang terjadi pada masa peperangan atau konflik maka sikap rela berkorban adalah sikap yang sangat fundamental yang harus dimiliki oleh semua masyarakat di mana konflik dan peperangan itu terjadi. Rela berkorban adalah sikap yang tidak mengharap imbalan dan balasan dari apa yang telah dilakukannya, menjaga keutuhan negara dengan mendahulukan kepentingan negara di atas kepentingan pribadi atau golongan.

Rela berkorban merupakan sebuah sifat keihklasan yang ada pada diri manusia (Chaplin, 1999). Rela berkorban juga merupakan wujud dari implementasi sila ke tiga dari pancasila, yakni Persatuan Indonesia, dengan adanya persatuan senatiasa wujud pengorbanan sebab persatuan merupakan kebersamaan dalam suka maupun duka untuk mencapai satu tujuan kehidupan yang adil dan makmur. Rela berkorban menjadi krisis global yang berkepanjangan di tanah air, mulai masa penjajahan Belanda, masih banyak masyarakat yang tidak mau berkorban untuk membela tanah air, hal ini salah satu hal yang mendasar Tengku Muhammad Chik Pante Kulu mengarang hikayat perang sabil di mana dalam hikayat tersebut banyak terdapat pesan-pesan yang berguna bagi mereka yang telah mengorbankan harta benda da jiwa raga untuk negara.

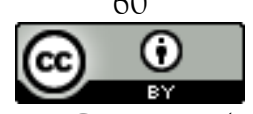

This work is licensed under a Creative Commons Attribution 4.0 International License 
VOLUME 14 NOMOR 1 TAHUN 2021

P-ISSN : 1979-9357

E-ISSN : 2620-5858

Krisis global saat ini saat ini, ditandai dengan sifat manusia yang tidak lagi mau memperhatikan sesamanya, tidak ada rasa belas kasih terhadap sesama mereka, membiarkan negara dalam kerusuhan dan kekacauan tidak mau berpartisipasi dalam keamanan negara sikap acuh tak acuh terhadap kedaulatan negara, ini disebabkan minimnya pengorbanan yang terjadi dari masyarakat terhadap negaranya. Mencintai negara merupakan sebuah keharusan bagi seluruh rakyatnya, sebagaimana para tokoh Ulama Indonesia telah sepakat yakni mencintai negara adalah sebagian dari iman, dengan mencintai negara akan timbul pengorbanan, perjuangan untuk memiliki negara yang berdaulat adil dan makmur.

Tengku chik Pante Kulu dalam syairnya mendeskripsikan tentang pentingnya rela berkorban yakni dalam syair:

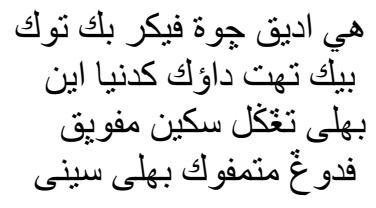

Hai adeek tjut pikee bak trook,

Bek that dawook keu doonja ini

Bah lee tinggay sikin meuputjook,

Peudeuong meutampook bah lee sinan.

Artinya;

Hai adek cut pikir hingga sampai

Jangan terlalu menikmati dunia ini

Biarkan tinggal pisau sampai pucuk

Pedang dengan warangkanya biarkan disitu

Hikayat yang diungkapkan oleh Tengku Chik Pante Kulu tersebut memberikan sebuah nilai akan pentingnya rela berkorban kepada kita semua, rela berkorban yang beliau maksudkan dalam syairnya yakni memiliki keikhlasan dalam semua perbuatan yang dia lakukan. Amalan yang seaharusnya dilakuka oleh manusia haruslah memiliki keikhlasan yakni sebagaimana Imam Al-Ghazali menjelaskan dalam kitabnya; pada hakikatnya manusia itu dalam ke adaan mati kecuali orang yang berilmu (alim), Orang berilmu sekalipun hidup namun pada hakikatnya ia tertidur, kecuali dia mengamalkan ilmunya, orang yang mengamalkan ilmunya banyak yang tertipu kecuali orang yang ikhlas (Al-Ghazali, 2006).

Rela berkorban dalam hikayat perang sabil Tengku Muhammad Chik Pante Kulu tercermin melalui beberapa sikap, pertama, meninggalkan kemewahan dunia. Salah satu sikap rela berkorban yang dituliskan oleh Tengku Muhammad Chik Pante Kulu yakni dengan meninggalkan kemewahan dunia, dimana beliau menyemangati kepada para rakyat agar mau meninggalkan kemewahan dunia, dan

61

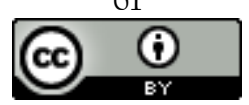

This work is licensed under a Creative Commons Attribution 4.0 International License 
VOLUME 14 NOMOR 1 TAHUN 2021

P-ISSN : 1979-9357

E-ISSN : 2620-5858

bergegas menuju medan perang. Kedua, berperang melawan kafir Belanda. Berperang melawan penjajahan Belanda merupakan inti dari hikayat perang sabil. Ketiga, mementingkan kepentingan bersama. Dimana pada masa Tengku Muhamad Chik Pante kulu pengorbanan yang mereka lakukan dengan melawan penjajah belanda akan memberikan kepentingan bersama untuk dapat merasakan negara yang aman dan berdaulat jauh dari para penjajahan belanda.

Dari rela sikap rela berkorban yang di jelaskan oleh Tengku Muhammad Chik Pante Kulu dalam syairnya maka akan memberikan beberapa manfaat yang nantinya akan memberikan kemaslahatan bagi ummat diantaranya yakni: pertama, mempertahankan kedaulatan negara. Kedaulatan negara yang berupa keutuhan dan kesatuan negara tanpa adanya kekacauan tanpa adanya pemberontaka didalamnya, jika hal ini (pengorbanan terealisasi dengan baik maka tidak akan lagi ada kekacauan dan kehancuran negara seperti yang kita takutkan karena pada semuanya telah mau berkorba yang terbaik untuk negaranya. Kedua, menghilangkan sifat egoisme. Egoisme atau dikenal dengan istilah ingin menang sendiri, ini merupakan sebuah sifat tercela yang ada pada diri manusia dimana dengan sifat ini manusia akan bertengkar sesamanya, memberikan permusuhan didalam kehidupan dunia aka timbulnya iri hati dendam, dengki dan khianat, jika dalam satu negara hal ini terus terjadi nihil akan terciptanya kedamaian seperti yang diharapkan oleh Undang-Undang. Rela berkorban pada dasarnya memberika yang terbaik kepada yang dia cintai maka sifat ini harus ada bagi setiap masyarakat yang mencintai negaranya agar terwujudnya negara seperti yang diharapkan.

Ketiga, memberikan rasa kasih sayang. Kasih sayang merupakan hal yang dibutuhkan oleh setiap insan, tanpa kasih sayang dunia ini akan hancur binasa, tanpa kasih sayang tidak aka wujud ketentraman dalam kehidupan dunia. Maka untuk memperoleh kasih sayang tersebut yakni melalui sifat rela berkorban dimana dengan pengorbanan mengambarkan kasih sayang seseorang terhadap orang lain. Hal ini dibuktikan ketika Saidina Ali Ra yang menggantikan posisi Rasululah SAW saat Hijrah beliau (Saidina Ali rela berkorban demi Rasulullah SAW yang juga mertuanya karna adanya rasa sayang dalam dirinya, Pengorbanan ini aka memberikan rasa kasih sayang kepada sesama insan dimana seseorang akan berkorban demi orang yang dia sayangi dan rela melakukan apa saja untuk kebahagian orang yang dia sayangi, begitu pula jika kita mencintai tanah air tentu kita rela berjuang, berkorban demi negara tercinta sekalipun nyawa sebagai taruhannya.

\section{Kepentingan Negara di Atas Kepentingan Pribadi}

Kepentingan dan kebutuhan adalah sesuatu yang melekat pada setiap makhluk hidup. Dengan demikian setiap makhluk hidup memliki kepentingan tertentu, apakah kepentingannya berhubungan dengan kepentingan sendiri atau kepentingannya berkaitan dengan kepentingan orng banyak. Demikan pula apa kah kepentingan searah dengan kepentingan bangsa dan negara ataukah sebaliknya kepentingannya bertentangan dengan kepentingan bangsa dan negara.

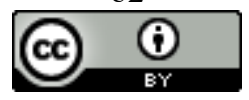

This work is licensed under a Creative Commons Attribution 4.0 International License 
VOLUME 14 NOMOR 1 TAHUN 2021

P-ISSN : 1979-9357

E-ISSN : 2620-5858

Bagi warga negara yang baik kepentingan bangsa dan negara lebih diutamakan bila dibandingkan dengan kepentingan pribadi atau kepentingan golongan tertentu. Perjuangan harus dibangun dari pemahaman yang sama dan atas dasar kepentingan yang sama. Sebagai contoh, perjuangan pada masa penjajahan Belanda maka setiap pejuang harus memiliki persepsi dan tujuan yang sama yaitu kemerdekaan. Akan tetapi apabila sebuah perjuangan tidak memiliki kepentingan yang sama maka perjuangan tersebut akan gagal.

Kepentingan di atas kepentingan pribadi atau golongan menjadi salah satu nilai yang terkandung didalamnya. Dalam hikayat perang sabil kepentingan negara dan agama harus diprioritaskan dari kepentingan yang lain. Di antara sya'ir hikayat perang sabil yang memotivasi untuk mendahulukan kepentingan agama dan negara bila dibandingkan dengan kepentingan kepentingan pribadi, kelompok, atau golongan tertentu.

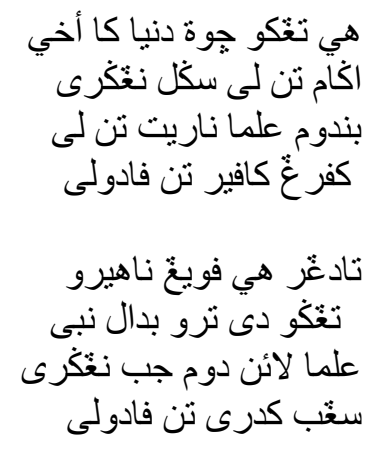

Wahee tungku tjut doonya ka akhe, Agama tan le sigala nanggro.

Bandum ulama narit tan le,

Keu Prang Kaphee tan Peuduli.

Tadeungo hai peu yang na hirau,

Teugku di Tiro badal Nabi.

Ulama laen dum jiba nanggro,

Seungab keudroo tan peuduli.

Artinya;

Wahai teungku dunia ini sudah berakhir

Agama tidak lagi tidak lagi segala negeri

Semua ulama tidak lagi berdakwa

Untuk perang kafir tidak lagi dipeduli

Kita dengar hai apa yang ada perhatian

Teungku di Tiro pengganti Nabi

Ulama lain di bawa negeri 


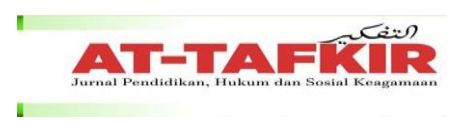

VOLUME 14 NOMOR I TAHUN 2021

P-ISSN : 1979-9357

E-ISSN : 2620-5858

\section{Berdiam diri tidak ada diperduli}

Teungku Chik Pantee Kulu dalam hikayat perang sabil menjelaskan bahwa pada saat perjuangan melawan Belanda yang disebut sebagai "kaphe", ulama tidak mempunyai perhatian serta kepedulian dalam perjuangan. Para ulama lebih banyak berdiam dari pada berdakwah untuk membangkitkan semangat masyarakat Aceh dalam melakukan perjuangan melawan penjajahan Belanda. Teungku Chik Pantee Kulu menjelaskan bahwa kepentingan negara menjadi kepentingan yang harus diutamakan bila dibandingkan dengan kepentingan pribadi dan golongan. Hal ini dapat dilihat dari ungkapan dalam sya'irnya "Keu Prang Kaphee tan Peuduli". Syair tersebut dapat dipahami bahwa masyarakat Aceh harus memiliki kepedulian terhadap serta mengutamakan kepentingan negara.

Teungku Chik Pantee Kulu mengungkapkan dalam hikayat perang sabil terdapat tiga bentuk sikap yang menunjukkan kepentingan negara di atas kepentingan pribadi atau golongan, yaitu pertama, perang melawan kafir Belanda. Belanda adalah penjajah yang merusak sendi-sendi agama dan mengambil hasil bumi yang ada di Aceh. sehingga Belanda adalah musuh dari masyarakat bangsa Aceh. Berjuang untuk memerangi Belanda merupakan kepentingan seluruh masyarakat Aceh, bukan kepentingan dari sebahagian atau orang atau kepentingan dari seseorang dari masyarakat Aceh. Teungku Chik Pantee Kulu dalam hikayat perang sabil menganjurkan untuk memerangi Belanda dan menyatakan bahwa Belanda adalah musuh dari masyarakat Aceh.

Kedua, meninggalkan kemewahan dunia. Kemewahan dunia dapat membuat manusia lupa akan keadaan sosial dimana individu itu berada. Hal ini dikarenakan manusia yang dalam hidupnya harta adalah segala-galanya dan akan menghalalkan segala cara untuk mendapatkan kemewahan dan materi. Sehingga manusia tersebut akan menjadi materialisme dan hedonisme dan mengukur kebahagian di dunia dengan kenikmatan serta kecukupan harta benda. Teungku Chik Pantee Kulu dalam hikayat perang sabil menganjurkan untuk mengorbankan harta benda yang dimilikinya untuk berperang dijalan Allah dengan wujud memerangi Belanda kafir laknatillah. Teungku Chik Pantee Kulu meyakinkan masyarakat Aceh jangan ragu dengan janji Allah, karena Allah telah berjanji dalam al-Qur'an bahwa barang siapa yang mebelanjakan hartanya kepada perang sabil maka Allah akan menggantinya dengan berlipat ganda dan surga adalah balasan yang tertinggi.

\section{Berjiwa Pahlawan}

Pahlawan berasal dari bahasa sansekerta yang akar katanya adalah "phala" dan "wan". Makna phala wan adalah manusia atau individu yang memiliki potensi serta kualitas individu yang dapat menghasilkan karya atau mendatangkan manfaat untuk bangsa, negara ataukah agamanya. Potensi individu juga harus diiringi oleh kepedulian individu atau rasa sensitifitas dalam memperjuangkan

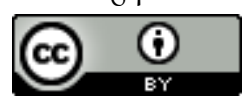

This work is licensed under a Creative Commons Attribution 4.0 International License 
VOLUME 14 NOMOR 1 TAHUN 2021

P-ISSN : 1979-9357

E-ISSN : 2620-5858

sebuah kebenaran dan berjuang untuk membela masyarakat yang tertindas dan menegakkan keadilan dalam sebuah negara, bangsa dan agama (Oktavia, 2015).

Dalam diri masyarakat Aceh jiwa pahlawan suatu hal yang tidak dapat diragukan lagi. Hal ini terbukti dengan perjuangan masyarakat Aceh untuk negeri dan bangsa Aceh dari masa penjajahan Belanda sebelum merdeka sampai pada masa merdeka dan berlanjut kepada masa setelah merdeka dan bergabung kenegara kesatuan Indonesia. Dengan jiwa pahlawan ini maka seseorang akan berani melakukan perlawanan kepada penjajahan Belanda yang dalam masyarakat Aceh adalah bangsa yang akan merusak ajaran agama di Aceh. Sehingga masyarakat Aceh melakukan serta menyatakan perang terhadap Belanda. Maju berjihad melawan para kafir laknatullah dalam perang untuk membela negara inilah yang disebutkan dengan pahlawan dalam teks hikayat perang sabil seperti ungkapan Tengku Muhammad Chik Pante Kulu;

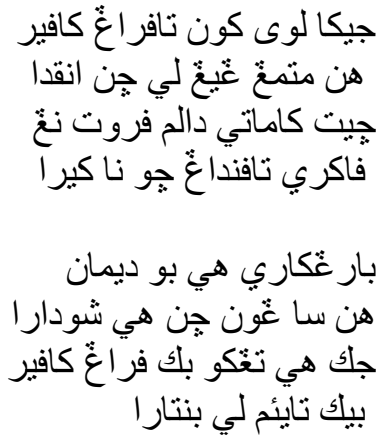

Djikalau kon taprang kaphee,

Han meuteumeung ngieng lee njang aneuqnda.

Tjit ka matee dalam prueet nang,

Pakri tapandang tjuba takira?

Baranggari hee budiman,

Han sa ngon njan hee sjeedara.

Djak hee teungku bak prang kaphee,

Bek taiem lee po beentara.

Artinya;

Jikalau bukan kita perangi kafir

Tidak dapat melihat lagi Ananda

Mungkin sudah meninggal dalam perut ibu

Bagaimana kita memandang coba kita pikir?

Bagaimana pun hai budiman

Tidak sama dengan itu hai saudara

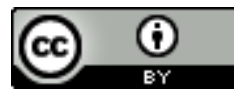

This work is licensed under a Creative Commons Attribution 4.0 International License 
VOLUME 14 NOMOR 1 TAHUN 2021

P-ISSN : 1979-9357

E-ISSN : 2620-5858

Pergi hai teungku keperang kafir

Jangan kita berdiam diri wahai bintara

Dalam syair Tengku Muhammad Chik Pante Kulu ada beberapa jiwa pahlawan yang harus dimiliki oleh seseorang, pertama, ketetapan Hati melawan (tidak mudah menyerah). Ketetapan hati atau dengan kata lain adalah teguh pendirian. Teguh pendirian adalah sesuatu yang harus dimiliki oleh pejuang. Dikarenakan dengan keteguhan hati ini seorang pejuang tidak mudah menyerah dengan berbagai macam kesulitan. Sehingga para pejuang membuat semboyan yang dapat membangkitkan semangat, di antaranya; "rawi-rawi rantas malang-malang putung artinya segala sesuatu yang menghalangi tujuan dan maksud harus disingkirka". "rawe-rawe rantas malang-malang tuntas". "iz kariman au mut syahidan artinya hidup mulia atau mati syahid". Dalam pejuang masyarakat Aceh juga terdapat selogan yang dapat membangkitkan semangat untuk berjuang, yaitu: "udep saree mate syahid yang maknanya hidup merdeka mati sayhid".

Kedua, pengorbanan. Dalam setiap perjuangan dan peperangan pastilah ada sebuah pengorbanan bahkan kita dituntut untuk berkorban. Loyalitas seorang pejuang sangat dituntut untuk mewujudkan tujuan perjuangan. Loyalitas dalam perjuangan dituntut secara totalitas, karena yang dikorbankan dapat berbentuk harta, keluarga, bahkan nyawa pun dapat dipertarukan dan dikorbankan dalam sebuah perjuangan.

\section{Tidak Mudah Menyerah}

Sikap tidak mudah menyerah adalah satu sikap yang harus dimiliki oleh setiap para pejuang. Hal ini dikarenakan apa yang terjadi di medan perang tidak lah sesuatu yang normal. Mereka terkadang tidak makan harus kehausan, tidur yang tidak teratur bahkan mereka tidak tidur untuk menjaga keselamatan, mereka harus berjalan keluar masuk hutan yang penuh rintangan dan bahawa. Jikalau para pejuang mudah menyerah maka mereka tidak akan pernah sukses dalam perjuangan mereka atau bahkan mereka tidak akan pernah berjuang. Dalam pertempuran di Surabaya pada tanggal 9 November 1945 Bung Tomo memberikan semangat untuk tidak menyerah dan putus asa, dengan ungkapan "Kita toenjoekkan bahwa kita adalah benar-benar orang jang ingin merdeka ... lebih baik kita hantjoer leboer dari pada tidak merdeka" (Kurniawan, 2016).

Semangat, tidak putus asa dan pantang menyerah yang dikatakan oleh Bung Tomo terlihat dari jiwa para pejuang yang lebih baik mati di medan perang untuk mempertahankan negara dan bangsa dari pada harus menyerah kepada penjajahan Belanda. Ketika mereka memberikan perlawanan kepada Belanda merka harus banyak yang dikorbankan bahkan nyawa sekali pun. Dalam hikayat perang sabil Tengku Muhammad Chik Pante juga memberikan motivasi untuk tidak menyerah dalam melawan penjajahan Belanda laknatillah. Walau dalam melakukan perlawanan tersebut harus meninggalkan istri, anak, dan kampung

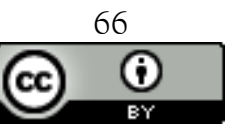

This work is licensed under a Creative Commons Attribution 4.0 International License 
VOLUME 14 NOMOR 1 TAHUN 2021

P-ISSN : 1979-9357

E-ISSN : 2620-5858

halaman. Tidak hanya sampai disitu, para pejuang tidak boleh menyerah sampai akhir hayat mereka.

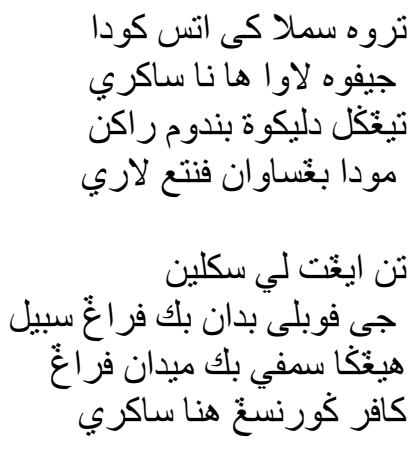

Trooh samlakoe ateuh kuda,

Dji poh lawan hana sakri.

Tinggai dilikoot bandum rakan,

Muda bangsawan pantang lari.

Tan ingat lee sekalian,

Dji publo badan bak prang sabi.

Hingga sampoe bak medan prang,

Kaphee gurangsang han sakri.

Artinya;

Sampainya suami di atas kuda

Di bunuh lawan tiada tara

Tinggal dibelakang semua teman

Muda bangsawan pantang lari

Tidak ingat lagi sekalian

Di jual tubuhnya pada perang sabil

Hingga sampai di medan perang

Kapir sangat ketakutan

Keberanian dan sugesti tumbuh pada jiwa masyarakat Aceh setelah hikayat perang sabil dibacakan dan didengar oleh mereka. Dalam hikayat perang sabil Teungku Chik Pantee Kulu menyebutkan sikap yang menunjukkan tidak mudah menyerah, yaitu; pertama, memotivasi diri sendiri. Motivasi dapat dikatakan sebagai semangat yang dengan semangat tersebut seseorang berusaha untuk mendapatkan sesuatu yang dinginkan dalam hidupnya. Motivasi yang diungkapkan oleh Tengku Chik Pantee Kulu dalam hikayat perang sabil, yaitu; barang siapa yang pergi berperang akan diberikan balasan dengan surge yang tinggi yang di dalamnya banyak ditemukan berbagai kenikmatan. Siapa yang mati

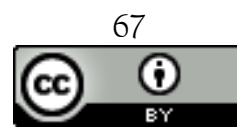

This work is licensed under a Creative Commons Attribution 4.0 International License 
VOLUME 14 NOMOR 1 TAHUN 2021

P-ISSN : 1979-9357

E-ISSN : 2620-5858

di medan perang akan ditunggu oleh Ainul Mardhiyah yang merindukan kedatangan suami mereka yang mati syahid dalam peperangan melawan kaphee.

Kedua, optimis. Optimis merupakan keyakinan terhadap sebuah harapan yang akan dicapai oleh seseorang dalam menjalanin sebuah usaha atau perjuangan. Optimis adalah keyakinan yang penting dalam sebuah perjuangan. Hal ini dikarenakan dengan keyakinan tersebut para pejuang memiliki sebuah harapan dan impian untuk masa yang akan datang. Kemerdekaan dan kebebasan adalah sesuatu yang awalnya sebuah harapan dan cita-cita yang dimiliki oleh para pejuang. Jikalau tanpa ada sebuah harapan maka perjuangan seperti tidak ada tujauan yang akan diraih. Dengan rasa optimis dan semangan untuk mencapai sebuah tujuan dalam perjuangan maka kemerdekaan dapat dirasakan oleh bangsa tertentu. Sebagai contoh Indonesia yang merasakan kemerdekaan saat ini yang diraih dengan semangat dan optimis dari para pejuang dalam melakukan perjuangan. Bung Karno dalam pidatonya dia mengatakan; "Kita bangsa besar, kita bukan bangsa tempe. Kita tidak akan mengemis, kita tidak akan minta-minta, apalagi jika bantuan-bantuan itu diembel-embeli dengan syarat ini syarat itu! Lebihbaik makan gaplek tetapi merdeka, dari pada makan bestik tapi budak" (Adams, 2019).

\section{Penutup}

Dari penjelasan di atas maka dapat disimpulkan bahwa; pertama, pengertian nasionalisme dalam Encyclopedia Britania, nasionalisme adalah keadaan jiwa setiap individu yang merasa bahwa setiap orang memiliki kesetiaan dalam keduniaan (sekuler) tertinggi kepada Negara kebangsaan, dan International Encyclopedia of tho Social Sciences, nasionalisme adalah suatu ikatan yang mengikat kesatuan masyarakat modern dan memberi keabsahan terhadap klaim (tuntutan) kekuasaan. Nasionalisme adalah suatu paham yang menganggap bahwa kesetiaan tertinggi atas setiap pribadi harus diserahkan kepada negara kebangsaan atau nation state. Kedua, terdapat lima nilai nasionalisme dalam hikayat perang sabil yang dikarang oleh Teungku Chik Pantee Kulu, yaitu; cinta tanah air, rela berkorban, kepentingan negara di atas kepentingan pribadi, berjiwa pahlawan, dan tidak mudah menyerah.

\section{Daftar Pustaka}

Adams, C. (2019). Bung Karno Penyambung Lidah Rakyat. Yogyakarta: Media Pressindo.

Alfian, I. (1992). Sastra Perang Sebuah Pembicaraan Mengenai Hikayat Perang Sabil. Jakarta: Balai Pustaka.

Al-Ghazali. (2006). DNA Mata Hati: Mukasyafatul Qulub. Jakarta: Shahih.

Alwi, H. (2007). Kamus Besar Bahasa Indonesia. Jakarta: Balai Pustaka.

68

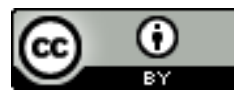

This work is licensed under a Creative Commons Attribution 4.0 International License 
VOLUME 14 NOMOR 1 TAHUN 2021

P-ISSN : 1979-9357

E-ISSN : 2620-5858

Asy'ari, H. (2007). Cahaya Penerang Jiwa. Jakarta: Pustaka Tebu Ireng .

Chaplin, J. P. (1999). Kamus Lengkap Psikologi. Jakarta: Rajawali Press.

Chotib, D., \& dkk. (2007). Kewarganegaraan Menuju Masyarakat Madani. Jakarta: PT. Ghalia Indonesia.

Drewes, G. W. (1979). Hikayat Po Cut Muhamad, An Achehness Epic. Leiden: The Hague Martinus Nijhoff.

Hasjmy, A. (1958). Himpunan Hadi Madja . Banda Aceh: Dinas Pendidikan Dasar dan Kebudayaan.

Hasjmy, A. (1977). Apa Sebab Rakyat Aceh Sanggup Berperang Puluhan Tahun Melawan Agresi Belanda. Jakarta: Bulan Bintang.

Hazm, Ibnu, Thuq Al-Hamamah, fi Al-Ilfah wa Al-Ullat. (2005). (A. Badruzzaman, Trans.) Jakarta: PT. Serambi Ilmu Semesta.

Herdiawanto, \& Jumanta , H. H. (2010). Cerdas, Kritis, dan Aktif Berwarganegara. Jakarta: Erlangga.

Hutauruk. (1984). Gelora Nasionalisme Indonesia. Jakarta: Erlangga.

Junanto, S. (2013). Civic Education. Surakarta: Fataba Press.

Kamilin. (2014). Cinta dalam Pandangan Penghafal Alquran. Malang: Fakultas Pendidikan Psikologi Universitas Negeri Malang.

Kurniawan, A. T. (2016). Bung Tomo 1920-1981 Jakarta: 2016. Jakarta: Kepustakaan Populer Gramedia.

Muhibbuddin, M. (2014). Bung Hatta: Kisah Hidup dan Pemikiran sang Arsistek Kemerdekaan. Yogyakarta: Araska Publisher .

Mustari, M. (2014). Nilai Karakter Refleksi Untuk Pendidikan. Jakarta: PT. Raja Grafindo Persada.

Oktavia, D. (2015). Ensiklopedia Pengetahuan Kewarganegaraan. Depok: Optima Intelijensia.

Retno, L. (2007). Pendidikan Kewarganegaraan. Jakarta: Gelora Aksara Pratama.

Rosyada, d. (2003). Pendidikan Kewarganegaraan (Civic Education) Demokrasi, Hak Asasi Manusia dan Masyarakat Madani. Jakarta: Pustaka Nasional.

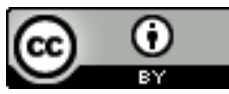

This work is licensed under a Creative Commons Attribution 4.0 International License 


\section{AT-TAFTIR}

VOLUME 14 NOMOR I TAHUN 2021

P-ISSN : 1979-9357

E-ISSN : 2620-5858

Setiawan, Z. (2016). Nasionalisme NU. Jakarta: Aneka Ilmu.

Yatim, B. S. (1999). Islam, dan Nasionalisme. Jakarta: Logos Wacana Ilmu.

Zuhdy, H. (2018). 76 Fatwa Cinta. Yogyakarta: Telaga Aksara. 